\title{
Turistlerin Gıda Güvenliği Bilgisinin Şikâyet Etme Davranışına Etkisi
}

\section{The Impact of Tourists' Food Safety Knowledge on Complaining Behavior}

Doç. Dr. Nurettin AYAZ

Karabük Üniversitesi

Safranbolu Turizm Fakültesi

E-posta: nurettinayaz@karabuk.edu.tr
Kübra SÜNBÜL

Karabük Üniversitesi

Sosyal Bilimler Enstitüsü

E-posta: kubra94sunbul@gmail.com

\section{Öz}

$\mathrm{Bu}$ araştırmada restoran işletmelerinden yiyecek ve içecek hizmeti talep eden turistlerin şikâyet etme davranışına gıda güvenliği bilgisinin etkisi araştırılmaktadır. Bu çerçevede İzmir ilini ziyaret eden ve restoran işletmelerinden hizmet talep eden 532 yerli turistten anket tekniği kapsamında veri toplanmıştır. Anket verilerinin analizi kapsamında yerli turistlerin gıda güvenliği bilgileri için çapraz kirlenme, kişisel hijyen, temizlik ve doğru pişirme/saklama olmak üzere dört boyut tespit edilmiştir. Yerli turistlerin şikâyet etme davranışları için ise şikâyet etme bilinci, şikâyet etme eğilimi, duygusal tepki, firmanın cevap verebilirliği, davranışsal tepki ve şikâyet yöntemi olmak üzere altı boyut belirlenmiştir. Araştırma sonucunda görülmüştür ki gıda güvenliği bilgisi ile şikâyet etme davranışı arasındaki ilişkiye yönelik basit doğrusal regresyon analizi kapsamında, gıda güvenliği bilgisinin şikâyet etme davranışını etkilediği belirlenmiştir.

Anahtar Kelimeler: Gıda, gıda güvenliği, turist davranışı, şikâyet etme, İzmir.

\begin{abstract}
In this research, the effect of food safety knowledge on the complaining behavior of tourists who request food and beverage services is investigated. Data were collected from 532 local tourists who visited İzmir province and demand service from restaurant operators in this framework. Within the scope of analysis of survey data, four dimensions for food safety information of domestic tourists were determined as crosscontamination, personal hygiene, cleaning and proper cooking/storage. For domestic tourists' complaining behaviors, six dimensions were determined namely thought of complaining, prone to complain, emotional reaction, company expectation, behavioral response and grievance method. The results have been revealed that food safety knowledge affects complaints behavior within the context of simple linear regression analysis of the relationship between food safety information and complaining behavior.
\end{abstract}

Key Words: Food, food safety, tourist behavior, complaining, İzmir. 


\section{Giriş}

İnsan yaşamının temeli olan beslenme kapsamında gıdalar, önemli bileşenlerdir. Bununla birlikte gıdaların güvenli olarak hazırlanmaması halen önemli bir sorundur. Basit gıda prosedürlerinin takip edilmemesi, gıdaları güvensiz gıdalar haline dönüştürmekte, güvensiz gıda tüketimi sonucunda meydana gelen gıda kaynaklı hastalıklar ölümlere ve ciddi tedavi süreçlerine neden teşkil edebilmektedir. Bu olumsuz durumlara karşı işletme sahipleri, yöneticiler ve çalışanların hukuki bir sorumluğuna dikkat çekilmekte, gıda kaynaklı hastalıklar konusunda bilgili olmaları beklenmektedir.

Gıda kaynaklı hastalıklar, son yıllarda birçok ülkede önemli bir sorundur. Bu nedenle toplum sağlığının korunması bağlamında gıda güvenliği önemli bir konudur (www.who.int). Ayrıca gıda güvenliği, taşıdığı riskler nedeniyle satın alma kararları veren tüketiciler için de önemlidir. Bu nedenle ağırlama hizmetleri sunan işletmeler (otel, hastane, huzur evi, cezaevi, yurtlar, askeri kışlalar) gıda güvenliği konusundaki bilgi ve becerilerini geliştirmelidirler (Purnomo, 2006: 1). İşletmelerin bilgi ve becerilerini geliştirme sürecinde başvurabilecekleri yöntemlerden bir tanesi de müşteri geri bildirimleridir. Dilek veya şikâyet şeklinde ortaya çıkabilen müşteri geri bildirimleri, turizm sektöründe tüketicilerin memnuniyeti kapsamında oldukça önemlidir. Bir turistin seyahat deneyimi sonrası memnuniyet değerlendirmesinde gıdalar, tekrar ziyaret etme eğilimi sergilenme ve ziyareti başkalarına tavsiye etmede belirleyici özellikleri ile öne çıkarlar (Ayaz ve Sünbül, 2018).

Tüketici davranışı literatüründe (Kotler vd., 2005) klasik karar verme süreci; ihtiyacı farkı etme, bilgi araması, alternatiflerin değerlendirilmesi, ürün/hizmet seçimi ve tüketim sonrası değerlendirme olarak öngörülmekte ve pazarlamacıların tüketicinin bu hareketlerine odaklanması beklenmektedir. Bununla birlikte tüketicinin istek ve intiyaçları, kişiliği, algısı, tutumu, inançları ve içinde bulunduğu toplumun sosyokültürel faktörleriyle (aile, kültür, sınıf) şekillenen, tüketicilerin psikolojik ve sosyal isteklerinin etkisiyle gerçekleşen tüketici davranışları oldukça karmaşıktır. Bu süreçte tüketicilerin isteklerine uygun beklentilerinin önceden tespit edilmesi, beklentilerine uygun mal ve hizmetler sunulması, sunulan hizmette yaşanan başarısızlıkların giderilmesi, tatmin edici çözümlerin bulunması ve müşteri şikâyetlerinin en aza indirilmesi için müşterilerin bilgilerine başvurmak önemli bir gerekliliktir (Mucuk, 2009: 69; Gümüşbuğa, 2016: 78; Çatı vd., 2010: 430)

Tüketicilerin satın aldıkları mal/hizmet sonrası geri bildirimleri kapsamında şikâyet etme davranışı hizmet verilen sektöre göre farklılık arz eden bir durumdur. Özellikle yiyecek ve içecek hizmetleri gibi kırılgan işkollarında hizmet sunan personelin bilgisizliği, serviste yaşanan gecikmeler, fiyat ve gıdaların güvenliği tüketicilerin şikâyetçi oldukları durumlardır (Şahin vd., 2014: 3). Bu durumlar içerisinde tüketicilerin zehirlenme ve hastalanma riskleri nedeniyle gıda güvenliği şikâyetler içerisinde öncelikli ele alınması ve göz ardı edilmemesi gereken bir durumdur. Turizm sektöründe bu durum, sektörün gelişmesini olumsuz yönde etkiler (Türksoy ve Altıniğne, 2008: 610). Çünkü sektörel işletmeler için toplumsal sorunlara duyarlılık ve etik davranışlar önemlidir (Türker ve Uçar, 2013: 177).

Yiyecek içecek işletmelerini tercih eden turistlerin, gıda güvenliği bilgisinin şikâyet etme davranışına olan etkisinin ortaya çıkarılması amacıyla hazırlanan bu çalışma ile yiyecek içecek işletmelerini tercih eden turistlerin gıda güvenliği üzerine bir bakış açısı geliştirmek, hizmet sektöründe gıda güvenliği mücadele konusunda yiyecek içecek işletmelerine yol göstermek, turizm işletmelerinde gıda güvenliğinden 
kaynaklanabilecek sorunların önlenmesine yiyecek ve içecek işletmeleri düzeyinde destek sağlamak hedeflenmektedir. Bununla birlikte çalışma, Türkiye turizminde önemli bir varış noktası olan İzmir ili özelinde yiyecek ve içecek hizmetlerine yönelik yeni anlayışların geliştirilmesi açısından önem arz etmektedir. Ayrıca araştırmanın yiyecek içecek sektöründe gıda güvenliği konusunda literatür zenginliği oluşturabileceği düşünülmektedir.

$\mathrm{Bu}$ çalışmada İzmir ilini ziyaret eden turistlerin yiyecek içecek işletmeleri hakkında gıda güvenliği bilgilerinin şikâyet etme davranışına etkilerinin belirlenmesi için uygulanan anket verileri yorumlanarak sonuçlar değerlendirilmiştir.

\section{Literatür İncelemesi}

Gıda güvenliği, gıdalarda oluşabilecek biyolojik, fiziksel, kimyasal ve her türlü zararların ortadan kaldırılması için alınan önlemler bütünü olup, daha çok insan sağlığı için tehlike arz eden güvenilir ve tüketime uygun olmayan gıdalarla ilgilidir (www.arastirma.tarim.gov.tr). Gıda güvenliği, sağlıklı gıdaların dağıtımını sağlamak için gıda üretimi, işleme, depolama, nakliye ve saklama aşamalarında gerekli kurallara uyulma ve önlem alınma durumu olarak da ifade edilmektedir (Yılmaz vd., 2015: 673).

Tüketiciler için gıdaların tüketilmesinden kaynaklanan sorunlar, sürekli bir artış eğilimi göstermektedir. Bu durumla birlikte gıda güvenliği konusundaki kaygılar diğer gıda işletmelerinde olduğu gibi restoran işletmeleri için de önemini artırmaktadır. Bu kapsamda restoranlarda gıda güvenliği ve gıda hijyeni ile ilgili bilgilere duyulan ilgi de artmaktadır. Bu ilgi artışının temel nedenlerini ise tüketicilerin gıda güvenliğine yönelik eğilimleri, dışarıda yemek yiyen kişi sayısının artması, teknolojik yenilikler ve gıda tedarik zincirindeki değişimler oluşturmaktadır (Sneed ve Strohbehn, 2008: 1170).

Gelişen teknoloji ve ülkelerin refah düzeyindeki yükseliş, yaşam standartlarını değişmesine neden olmuş ve bunun sonucunda da daha bilinçli tüketiciler ortaya çıkmıştır. Bilinçli tüketiciler sağlıklı beslenme kapsamında gıda güvenliğini önemser hale gelmektedirler (Başaran, 2016: 24). Bu nedenle gıda güvenliği konusu, son yıllarda tüm ülkelerde hem halk sağlığı hem de ekonomik boyutundan dolayı önemi giderek artan ve tüketiciler açısından endişe duyulabilecek bir konu haline gelmektedir (www.gidamo.org.tr).

Tüketiciler, satın aldıkları ve tükettikleri yiyeceklerin özellikleri yanı sıra güvenli olup olmadıkları konusunda da endişe göstermektedirler (Beulens, 2005: 482). Bu risk temelli yaklaşım kapsamında restoran işletmelerinde güvenli gıdaların hazırlanmasına yönelik uygulamalar göreceli olarak önem kazanmakta, gıda işleyicileri arasında gıda güvenliği konusunda iyi düzeyde bilgi sahibi olma ve bu bilginin gıda işçiliği uygulamalarında etkin bir şekilde uygulanması konusunda genel bir yaklaşım kendini kabul ettirir hale gelmektedir (Bolton vd., 2008: 291). Bununla birlikte çapraz bulaşma, el yıkamayı göz ardı etme, uygun olmayan gıda depolama ve yetersiz pişirme gıda güvenliğinin önemli öğeleri olarak gösterilmesine rağmen gıda işgörenlerinin yanlış bilgi ve tutumları nedeniyle gıda kaynaklı hastalıklar yaygınlaşmaktadır (Dehghan vd., 2017: 63). Gıdalara uygun olmayan şekilde temas (\%60), kötü kişisel hijyen (\%31), çapraz kirlenme $(\% 26)$ ve yetersiz pişirme (\%18) gıda kaynaklı hastalıklarda önemli risk faktörleri arasında gösterilmektedir (Bolton vd., 2008: 292).

Günümüzde müşteriler, satın alım süreci ve sonrasında elde ettiği bilgiler neticesinde daha dikkatli olup bu bilgiler doğrultusunda davranışlar sergilemektedir. Bu nedenle yüksek kalite beklentilerinin oluşması ve bu beklentilerin karşılanamaması 
müşterilerde olumsuz davranışlar ortaya çıkarmaktadır. Bu davranışlardan bir tanesi de şikâyet etmedir. Şikâyet etme; "müşterilerin satın aldıkları ürün veya hizmetler hakkında memnuniyetsizliğini yansıtan olumsuz bir dışa vurum" (Defranco vd., 2005: 174) veya "müşterilerin beklentilerinin karşılanmadığını ifade etmek için yaptığı olumsuz geri bildirimlerdir" (Bell vd., 2004: 116).

Şikâyetler hem müşteriyi hem de işletmeleri etkilemektedir. Müşterilerin şikâyette bulunması işletmelerin zayıf yönlerini görmesine ve buna ilişkin pazarlama programları geliştirmesine olanak sağlar. Bu şekilde işletmeler kendinden kaynaklanan kusurları düzelterek müşterileri kaybetme riskini azaltmış olur. Bununla birlikte şikâyetler işletmelerde müşteri memnuniyeti sağlamak için yeni fikirlerin ortaya çıkmasına ve ürün ve hizmetlerin geliştirilmesine katkı sağlar (Usta, 2006: 124).

Restoran işletmelerinde şikâyet davranışı; genel olarak restorana geri gelme, tekrar gelmeme, şikâyet etme, bahşiş verme, kulaktan kulağa şeklinde meydana gelebilir. Ancak her zaman bu durum böyle tespit edilemeyebilir. Çünkü bazı davranışların bir kısmı tekrar geri gelmeme gibi pasif davranışlar şeklinde olabilir. Şikâyetlerin her zaman yazılı ya da doğrudan yöneticiye iletilmediği göz ardı edilmemelidir. Bu durumla birlikte şikâyet davranışı çevrelerindeki kişilere olumsuz söylemde bulunmak, bir daha gitmemek, yönetime şikâyet etmek, şikâyet kutularına not bırakmak, basın araçlarına veya yönetime şikâyet etmek şeklinde olabilir (Kitapcı, 2008; Albayrak, 2013).

\section{Yöntem}

Toplumsal yaşamda ortaya çıkan dönüşümlerden bir tanesi de insanların kendi konutları dışında yemek yeme eylemidir. Artan bir şekilde devam eden bu eylemin sonucu olarak yeme ve içme pazarındaki işletmelerin göreceli olarak sayıca artışı, beraberinde bazı sorunları da meydana getirmektedir. Bu sorunlardan birisi de müşteri ilişkileri kapsamında otaya çıkabilecek şikâyet durumudur. Bu kapsamda gıda güvenliği bilgisi ve şikâyet etme davranışının iki ayrı boyutta incelendiği araştırmada turistlerin gıda güvenliği bilgisinin şikâyet etme davranışına etkisi betimsel ve nicel yöntemlerle ortaya konulmaktadır.

\subsection{Araştırmanın Problemi, Amacı ve Önemi}

$\mathrm{Bu}$ araştırmada bir yiyecek ve içecek işletmesinden hizmet talep eden turistlerin gıda güvenliği bilgilerinin şikâyet etme davranışlarını etkileyip etkilemediğinin ortaya çıkarılması kapsamında "restoranlardan hizmet talep eden turistlerin gıda güvenliği bilgilerinin şikâyet etme davranışlarını etkileyip etkilemediğinin belirlenmesi" bu araştırmanın problemini oluşturmaktadır.

Bu araştırmada WHO tarafından ciddi şekilde önemsenen gıda güvenliğine bilinç oluşturma açısından yaklaşılmaktadır. Bu kapsamda bir yiyecek ve içecek işletmesini ziyaret eden tüketicilerin gıda güvenliği bilgisinin şikâyet etme davranışına etkisinin bulunup bulunmadığının ortaya çıkarııması amaçlanmaktadır. Bu amaç doğrultusunda hazırlanan çalışmanın çıktıları sonucunda ayrıca aşağıda belirtilen hususlara katkı yapması beklenmektedir:

-Yiyecek-içecek işletmelerini tercih eden turistlerin gıda güvenliği bilgisi üzerine bir bakış açısı geliştirmek, göstermek,

-Hizmet sektöründe gıda güvenliği boyutunda yiyecek içecek işletmelerine yol 

oluşturmak,

-Yiyecek-içecek işletmelerinde ortaya çıkabilecek şikâyetler için farkındalık

-Yiyecek-içecek işletmelerinde gıda güvenliği boyutunda ortaya çıkabilecek şikâyetlerin çözümlenmesine yardımcı olmak.

$\mathrm{Bu}$ kapsamda araştırmanın modeli ve tanımlanan amaçlara ulaşabilmek için öngörülen hipotezler şu şekilde belirlenmiştir:

\section{Şekil 1: Araştırma Modeli}

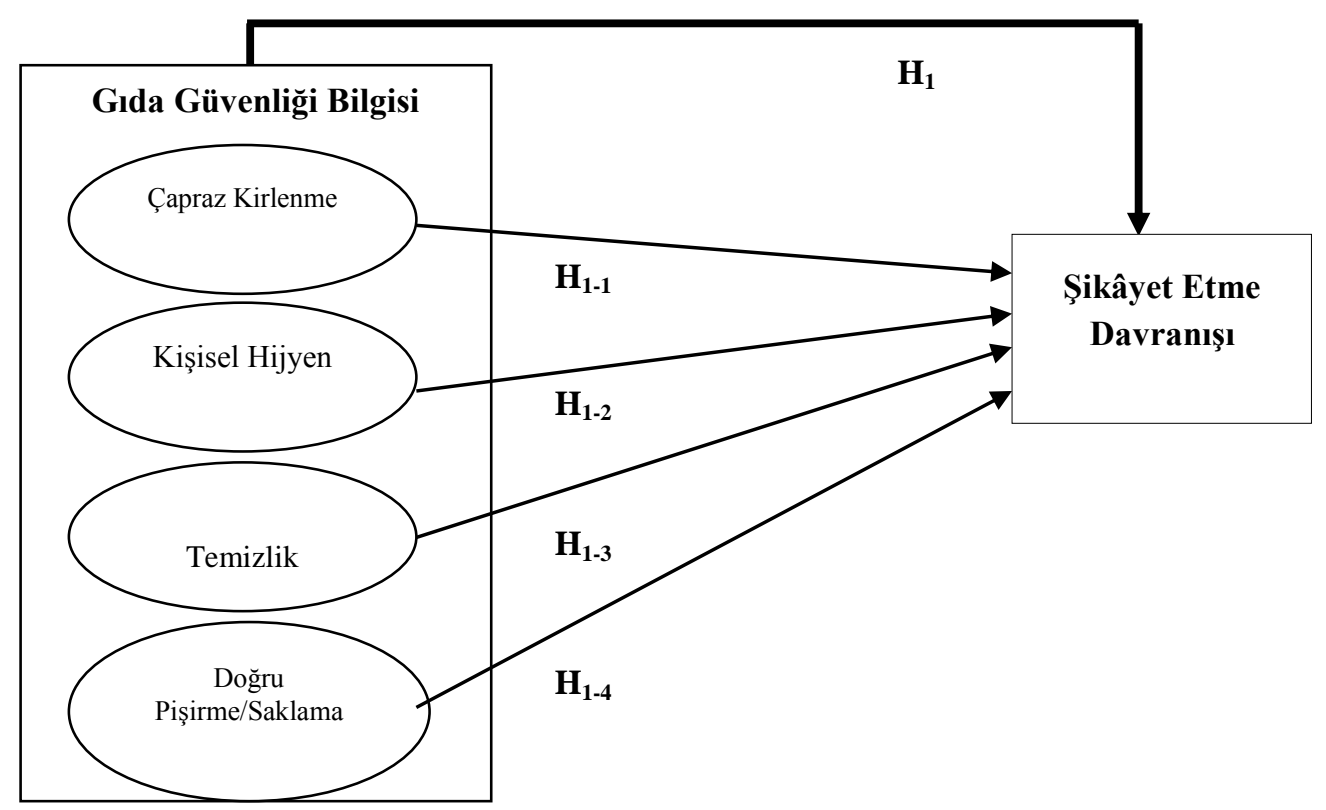

$\mathbf{H}_{1}$ : Restoranlardan yiyecek ve içecek hizmeti talep eden turistlerin gıda güvenliği bilgileri şikâyet etme davranışını etkiler.

$\mathbf{H}_{1-1}$ : Restoranlardan yiyecek ve içecek hizmeti talep eden turistlerin çapraz kirlenme bilgileri şikâyet etme davranışını etkiler

$\mathbf{H}_{1-2}$ : Restoranlardan yiyecek ve içecek hizmeti talep eden turistlerin kişisel hijyen bilgileri şikâyet etme davranışını etkiler.

$\mathbf{H}_{1-3}$ : Restoranlardan yiyecek ve içecek hizmeti talep eden turistlerin temizlik bilgileri şikâyet etme davranışını etkiler.

$\mathbf{H}_{1-4}$ : Restoranlardan yiyecek ve içecek hizmeti talep eden turistlerin doğru pişirme ve saklama bilgileri şikâyet etme davranışını etkiler.

\subsection{Araştırmanın Evreni ve Örneklem}

Bu araştırmada evren, 2017 yılında İzmir ilini ziyaret eden turist sayısı kabul edilmiştir. İzmir İl Kültür ve Turizm Müdürlüğü, 2017 verilerine göre İzmir ilini 659.462 yerli turistin ziyaret ettiği tespit edilmiştir. Araştırma alanının genişliği, zaman ve maliyet unsurları açısından örnekleme uygulanması öngörülmüştür. Örneklem büyüklüğünü hesaplamak 
için Ayaz'ın (2012) araştırmasında kullanmış olduğu örnekleme formülü uygulanmıştır. Araştırmada güven aralığı \%+-5, Z değeri ise 1,96 olarak kabul edilmiştir. Örneklem sayısının hesaplanması kapsamında ulaşılması gereken örneklem sayısı Sekeran (2003) tarafından geliştirilen örneklem büyüklüğü tablosu çerçevesinde 384 olarak tespit edilmiştir.

\subsection{Verilerin Toplanması ve Analizi}

Yerli turistlerin gıda güvenliği bilgilerinin şikâyet etme davranışlarına etkisinin ortaya çıkarılması bağlamında gerçekleştirilen bu araştırmada anket tekniğinden yararlanılmıştır. Araştırmada kullanılan anket ölçeği geliştirme sürecinde, Keng ve Liu (1997), Liu ve Jang (2009), Şahin, Çakıcı ve Güler (2014) ve Ayaz ve Acar (2018) tarafından gerçekleştirilen çalışmalardan faydalanıımıştır. Bununla birlikte araştırma ölçeğine ilişkin sorular akademisyen görüşü kapsamında geliştirilmiştir.

Anket ölçeği ön test kapsamında 2018 yılında İzmir'i ziyaret eden ve kolayda örneklem ile seçilen 100 yerli turiste gıda güvenliği bilgisi ile ilgili 35 , şikâyet etme davranışı ile ilgili 26 ifadeden oluşan ölçek uygulanmıştır. Ön test verilerine faktör analizi ve güvenirlik analizi yapılmıştır. Yeniden düzenlenen anket, araştırmacı tarafından kolayda örneklem kapsamında yüz yüze görüşme yöntemi ile yerli turistlere Mart-Mayıs 2018 döneminde uygulanmıştır. Anketi cevaplamayı kabul eden 600 kişiden veri toplanmış olsa da toplanan anketlerin 68 tanesinin eksik veya hatalı olması itibariyle araştırma kapsamında kullanılmaya uygun olmadığı değerlendirilerek, analizin dışında tutulmasına karar verilmiş ve toplam 532 adet katılımcıdan elde edilen veriler analizlerde kullanılmıştır. Anket geri dönüş oranı \%88 olarak hesaplanmıştır.

Yerli turistlerin gıda güvenliği bilgisi ve şikâyet etme davranışlarını ortaya çıkarmaya yönelik olarak hazırlanan anket, üç kısımdan oluşmaktadır. Anketin birinci bölümünde; katılımcıların demografik (cinsiyet, medeni durum, yaş, eğitim durumu, aylık gelir, meslek) diğer (ziyaret nedeni, kalış süresi, seyahati boyunca restoranda yemek yeme sayısı, gıda güvenliği bilgisi) özellikleri için sınıflama ölçeği; ikinci bölümde şikâyet etme davranışı ve üçüncü bölümde ise gıda güvenliği bilgisine ilişkin aralıklı ölçek kapsamında geliştirilen sorular yer almıştır. Aralıklı ölçek olarak 5'li Likert Ölçeği'nin kullanıldığı bu araştırmada şikâyet etme davranışına ilişkin sorular; "1=Hiç Katılmıyorum; 2=Katılmıyorum; 3=Orta Düzeyde Katılıyorum; 4=Katılıyorum; $5=$ Tamamen Katılıyorum" gıda güvenliği bilgisine ilişkin sorular ise "1=Hiç Şikâyet Etmem; 2=Şikâyet Etmem; 3=Kararsızım; 4=Şikâyet Ederim; 5=Kesinlikle Şikâyet Ederim" şeklinde kodlanmıştır.

$\mathrm{Bu}$ araştırma için çarpıklık ve basıklık katsayıları; -0,044 ve 0,405 (şikâyet davranışı), $-0,158$ ve 0,013 gıda güvenliği aralığında gözlenmiştir. Bu bağlamda Skewness ve Kurtosis değerlerinin (-+) 1 aralığında olması parametrik testlerin yapılabileceğini göstermektedir (Deniz vd., 2014: 309). Elde edilen veriler kapsamında, gıda güvenliği bilgisi ve şikâyet etme davranışı ilişkisinin test edilmesinde "korelasyon" ve "regresyon" analizleri kullanılmıştır. Ana hipotezin test edilmesinde korelasyon ve basit doğrusal regresyon, alt hipotezlerin test edilmesinde ise korelasyon ve çoklu regresyon analizleri kullanılmıştır.

\section{Bulgular}

Araştırmada İmir ilindeki restoranları ziyaret eden yerli turistlere uygulanan gıda güvenliği bilgisi ve şikâyet etme davranışı ölçekleri sonucunda elde edilen bulgulara yer verilerek araştırma amaçları doğrultusunda yorumlanmıştır. 
Araştırma katılımcıların demografik ve diğer özelliklerinde Tablo 1'de görüldüğü üzere cinsiyet açısından erkekler $(\% 55,6)$, medeni durum bakımından bekarlar $(\% 53,4)$, yaş boyutunda $18-25$ yaş $(\% 39,1)$, eğitim durumu açısından lisans eğitimli olanlar $(\% 59,4)$, gelir durumu yönünden 0-1000 TL $(\% 26,3)$, meslek açısından öğrenciler (\%24,8), İzmir ilini ziyaret nedeni açısından akraba, arkadaş ziyareti $(\% 33,1)$, kalış süresi bakımından $1-3$ gün $(\% 36,1)$, yemek yeme sayısı açısından beş ve üzeri $(\% 22,6)$, gıda güvenliği bilgi düzeyi yönünden ise bilgim yok $(\% 70,7)$ şeklinde tespit edilmiştir.

Tablo 1: Katılımcılara İlişkin Tanımlayıcı Bilgiler

\begin{tabular}{|c|c|c|c|c|c|c|c|}
\hline Değişkenler & Gruplar & $\mathbf{f}$ & $\%$ & Değişkenler & Gruplar & $\mathbf{f}$ & $\%$ \\
\hline \multirow{3}{*}{ Cinsiyet } & Kadın & 236 & 44,4 & \multirow{10}{*}{ Meslek } & İşçi & 92 & 17,3 \\
\hline & Erkek & 296 & 55,6 & & Memur & 78 & 14,7 \\
\hline & Toplam & 532 & 100 & & Esnaf & 46 & 8,6 \\
\hline \multirow{3}{*}{ Medeni Durum } & Bekâr & 284 & 53,4 & & Serbest Meslek & 82 & 15,4 \\
\hline & Evli & 248 & 46,6 & & Ev Kadını & 38 & 7,1 \\
\hline & Toplam & 532 & 100 & & Emekli & 64 & 12,0 \\
\hline \multirow{6}{*}{ Yaş } & 18-25 yaş & 208 & 39,1 & & Öğrenci & 132 & 24,8 \\
\hline & 26-33 yaş & 98 & 18,4 & & İş Seyahati & 116 & 21,8 \\
\hline & 34-41 yaş & 56 & 10,5 & & Akraba, Arkadaş & 176 & 33,1 \\
\hline & 42-49 yaş & 102 & 19,2 & & Toplam & 532 & 100 \\
\hline & 50 yaş ve üzeri & 68 & 12,8 & \multirow{4}{*}{ Ziyaret Nedeni } & Tatil & 120 & 22,6 \\
\hline & Toplam & 532 & 100 & & Sağlik & 72 & 13,5 \\
\hline \multirow{5}{*}{ Ĕgitim } & İlköğretim & 38 & 7,1 & & Ĕgitim & 48 & 9,0 \\
\hline & Ortaöğretim & 96 & 18,0 & & Toplam & 532 & 100 \\
\hline & Ön lisans & 106 & 19,9 & \multirow{5}{*}{ Kalış Süresi } & Bir günden az & 116 & 21,8 \\
\hline & Lisans & 292 & 54,9 & & 1-3 gün & 192 & 36,1 \\
\hline & Toplam & 532 & 100 & & 4-6 gün & 80 & 15,0 \\
\hline \multirow{7}{*}{ Gelir } & 0-1000 TL & 140 & 26,3 & & 7 gün ve üzeri & 144 & 27,1 \\
\hline & $1001-2000 \mathrm{TL}$ & 98 & 18,4 & & Toplam & 532 & 100 \\
\hline & 2001-3000 TL & 104 & 19,5 & \multirow{8}{*}{$\begin{array}{l}\text { Yemek Yeme } \\
\text { Sayısı }\end{array}$} & 1 & 112 & 21,1 \\
\hline & $3001-4000 \mathrm{TL}$ & 80 & 15,0 & & 2 & 116 & 21,8 \\
\hline & $4001-5000 \mathrm{TL}$ & 72 & 13,5 & & 3 & 110 & 20,7 \\
\hline & 5001 TL ve üzeri & 38 & 7,1 & & 4 & 74 & 13,9 \\
\hline & Toplam & 532 & 100 & & 5 ve üzeri & 120 & 22,6 \\
\hline \multirow{3}{*}{$\begin{array}{l}\text { Gida Güvenliği } \\
\text { Bilgisi }\end{array}$} & Kurs/ders aldım & 156 & 29,3 & & & & \\
\hline & Bilgim yok & 376 & 70,7 & & & & \\
\hline & Toplam & 532 & 100 & & Toplam & 532 & 100 \\
\hline
\end{tabular}

İmir'i ziyaret eden yerli turistlerin şikâyet etme davranışlarına yönelik altı boyut (şikâyet etme bilinci, şikâyet etme eğilimi, duygusal tepki, firmanın cevap verebilirliği, davranışsal tepki, şikâyet yöntemi) ortaya çıkmıştır (Tablo 2). Restoranları ziyaret eden yerli turistlerin şikâyet etme davranışlarının faktör analizinde 20 yargıya ait 6 faktör için KMO Örneklem Ölçüm Değer Yeterliliği (Kasier-Meyer-Olkin) 0,78, Bartlett's 
Kürsellik Testi anlamlılık düzeyi; $p=0,000$ olup, varyans açıklama oranı; 64,95 ve güvenilirlik katsayısı ise; 0,82 olarak belirlenmiştir.

Tablo 2: Turistlerin Şikâyet Davranışlarına İlişkin Faktör Analizi

\begin{tabular}{|c|c|c|c|c|c|}
\hline Faktör & $\bar{x}$ & $\sigma$ & $\begin{array}{l}\text { Faktör } \\
\text { Yükü }\end{array}$ & $\begin{array}{c}\text { Cronbac } \\
\text { h } \\
\text { Alpha }\end{array}$ & $\begin{array}{l}\text { Varyans } \\
\text { Açiklama } \\
(\%)\end{array}$ \\
\hline Şikâyet Bilinci & 4,06 & 0,82 & & $\mathbf{0 , 8 0 3}$ & 13,683 \\
\hline Şikâyet, tüketicinin temel bir hakkıdır. & & & 0,799 & 0,818 & \\
\hline Şikâyette bulunmak kötü bir şey değildir. & & & 0,766 & 0,815 & \\
\hline $\begin{array}{l}\text { Yetersiz bir ürün veya hizmet için şikâyette bulunmak bir } \\
\text { görevdir. }\end{array}$ & & & 0,756 & 0,814 & \\
\hline Şikâyette bulunmak utanç verici bir şey değildir. & & & 0,716 & 0,822 & \\
\hline Şikâyet Eğilimi & 3,22 & 0,91 & & $\mathbf{0 , 7 5 0}$ & $\mathbf{1 2 , 0 4 0}$ \\
\hline $\begin{array}{l}\text { Uzun süre kullandığım ürünlerde şikâyet etme eğilimim } \\
\text { yüksektir. }\end{array}$ & & & 0,771 & 0,813 & \\
\hline Sık kullandığım ürünlerde şikâyet etme eğilimim yüksektir. & & & 0,769 & 0,813 & \\
\hline Ürünün fiyatı yüksek olduğunda șikâyet etme eğilimim artar. & & & 0,694 & 0,819 & \\
\hline Yanımda birisi olduğunda şikâyet eğilimim artar. & & & 0,657 & 0,826 & \\
\hline Duygusal Tepki & 3,56 & 0,88 & & 0,746 & $\mathbf{1 0 , 2 5 7}$ \\
\hline $\begin{array}{l}\text { Yetersiz bir ürün veya hizmet için şikâyette bulunmamak } \\
\text { beni rahatsı eder. }\end{array}$ & & & 0,821 & 0,818 & \\
\hline $\begin{array}{l}\text { Yetersiz bir ürün veya hizmet için şikâyet etmemek } \\
\text { sinirlerimi bozar. }\end{array}$ & & & 0,740 & 0,816 & \\
\hline Yetersiz bir ürün veya hizmete her zaman sinirlenirim. & & & 0,710 & 0,816 & \\
\hline Firmanın Cevap Verebilirliği & 3,08 & 0,89 & & $\mathbf{0 , 7 2 8}$ & $\mathbf{1 0 , 1 4 5}$ \\
\hline $\begin{array}{l}\text { İşletmeler şikâyet durumunda hatalı ürünlerinde geri ödeme } \\
\text { yapmaya hazırdırlar. }\end{array}$ & & & 0,830 & 0,826 & \\
\hline $\begin{array}{l}\text { İşletmeler genellikle şikâyetleri çözümlemede oldukça } \\
\text { yardımcıdırlar. }\end{array}$ & & & 0,778 & 0,824 & \\
\hline $\begin{array}{l}\text { İşletmeler genellikle şikâyet durumunda hatalı ürünlerini } \\
\text { değiştirmeye isteklidirler. }\end{array}$ & & & 0,742 & 0,824 & \\
\hline Davranışsal Tepki & 3,90 & 0,79 & & $\mathbf{0 , 6 8 8}$ & 9,444 \\
\hline $\begin{array}{l}\text { Çevremdeki insanları memnun kalmadığım bir işletmeye } \\
\text { gitmemeleri için yönlendiririm. }\end{array}$ & & & 0,853 & 0,825 & \\
\hline Memnun kalmadığım bir işletmeye bir daha gitmem. & & & 0,729 & 0,825 & \\
\hline $\begin{array}{l}\text { Çevremdeki insanlara bir işletmede } \\
\text { olumsuzlukları anlatırım. }\end{array}$ & & & 0,706 & 0,823 & \\
\hline Şikâyet Yöntemi & 3,79 & 0,76 & & $\mathbf{0 , 7 0 8}$ & 9,383 \\
\hline Hakkım olanı elde etmek için yasal yollara başvururum. & & & 0,726 & 0,814 & \\
\hline $\begin{array}{l}\text { Memnuniyetsizliğimde çözüm üretmeleri için işletme } \\
\text { yetkililerine rahatsızlığımı iletirim. }\end{array}$ & & & 0,705 & 0,814 & \\
\hline $\begin{array}{l}\text { Hakkım olanı elde etmek için sorunu işletme yetkililerine } \\
\text { aktarırım. }\end{array}$ & & & 0,645 & 0,815 & \\
\hline Toplam Cronbach Alpha / Varyans Açıklama (\%) & & & & $\mathbf{0 , 8 2 6}$ & 64,952 \\
\hline
\end{tabular}

KMO Örneklem Ölçüm Değer Yeterliliği: 0,788

Bartlett's Kürsellik Testi (Ki-kare / sd /p (anlamlılık düzeyi): 3611,747/ 190 / 0,000

Restoranları ziyaret eden yerli turistlerin gıda güvenliği bilgilerinin faktör analizinde 16 yargı gıda güvenliği bilgilerine yönelik dört boyut (çapraz kirlenme, kişisel hijyen, temizlik ve doğru pişirme/saklama) KMO Örneklem Ölçüm Değer Yeterliliği (Kasier-Meyer-Olkin) 0,85, Bartlett's Kürsellik Testi anlamlılık düzeyi; $p=0,000$ olup, varyans açıklama oranı; 60,44 ve güvenilirlik katsayısı ise; 0,86 olarak belirlenmiştir (Tablo 3). 
Tablo 3: Turistlerin Gıda Güvenliği Bilgilerine İlişkin Faktör Analizi

\begin{tabular}{|c|c|c|c|c|c|}
\hline Faktör & $\bar{x}$ & $\sigma$ & $\begin{array}{l}\text { Faktör } \\
\text { Yükü }\end{array}$ & $\begin{array}{l}\text { Cronbach } \\
\text { Alpha }\end{array}$ & $\begin{array}{c}\text { Varyans } \\
\text { Açıklama } \\
(\%)\end{array}$ \\
\hline Çapraz Kirlenme & 3,41 & 0,91 & & 0,817 & 19,540 \\
\hline Aynı kesim tahtasının birçok kesim işinde kullanılması. & & & 0,790 & 0,856 & \\
\hline Aynı bıçağın birçok kesim işinde kullanılması. & & & 0,768 & 0,863 & \\
\hline $\begin{array}{l}\text { Buzdolabında yiyeceklerin birbirine temas edecek şekilde } \\
\text { saklanması. }\end{array}$ & & & 0,712 & 0,857 & \\
\hline Gıdaların zemine temas edecek şekilde bekletilmesi. & & & 0,647 & 0,856 & \\
\hline Kişisel Hijyen & 3,71 & 0,69 & & 0,739 & 15,730 \\
\hline $\begin{array}{l}\text { Personelin vücudunun herhangi bir yerine dokunduktan } \\
\text { sonra ellerini yıkamaması. }\end{array}$ & & & 0,729 & 0,863 & \\
\hline Personelin saçlarıyla oynaması. & & & 0,696 & 0,866 & \\
\hline $\begin{array}{l}\text { Personelin yere düşen bir şeyi aldıktan sonra ellerini } \\
\text { yıkamaması. }\end{array}$ & & & 0,668 & 0,864 & \\
\hline Personelin hapşırdıktan sonra ellerini yıkamaması. & & & 0,652 & 0,865 & \\
\hline $\begin{array}{l}\text { Personel hapşırma/öksürmeyi elinin iç kısmına doğru } \\
\text { yapması. }\end{array}$ & & & 0,589 & 0,866 & \\
\hline Temizlik & 3,73 & 0,78 & & 0,764 & 14,592 \\
\hline $\begin{array}{l}\text { Kaşık, çatal ve bıçakların hijyenik olmayan biçimde tutularak } \\
\text { masaya bırakılması. }\end{array}$ & & & 0,759 & 0,864 & \\
\hline $\begin{array}{l}\text { Tabak ve bardakların parmaklar içine girecek şekilde } \\
\text { taşınması. }\end{array}$ & & & 0,706 & 0,861 & \\
\hline Tepsi kullanmadan elde bardak taşınması. & & & 0,705 & 0,862 & \\
\hline $\begin{array}{l}\text { Aynı kurulama bezi ile birçok farklı malzemenin (bardak, } \\
\text { tabak vb.) silinmesi. }\end{array}$ & & & 0,632 & 0,858 & \\
\hline Doğru Pişirme/Saklama & 3,73 & 0,72 & & 0,652 & 10,581 \\
\hline Yemeklerin sıcak olarak tutulmaması. & & & 0,639 & 0,864 & \\
\hline Et veya köftelerin iç kısımlarının tam olarak pişmemesi. & & & 0,610 & 0,865 & \\
\hline Pişmiş yiyeceklerin buzdolabı dışında bekletilmesi. & & & 0,516 & 0,856 & \\
\hline Toplam Cronbach Alpha / Varyans Açıklama (\%) & & & & 0,869 & 60,441 \\
\hline
\end{tabular}

KMO Örneklem Ölçüm Değer Yeterliliği: 0,851

Bartlett's Kürsellik Testi (Ki-kare / sd /p (anlamlılık düzeyi): 3023,670/ 120 / 0,000

Restoranlarda yiyecek ve içecek hizmeti talep eden turistlerin gıda güvenliği bilgilerinin şikâyet etme davranışlarına etkisinin belirlenmesi bağlamında ilk önce korelasyon yapılması öngörülmüş ve gıda güvenliği bilgisi ile şikâyet etme davranışı arasında anlamlı bir ilişkinin bulunup, bulunmadığı test edilmiştir.

Korelasyon analizi, iki değişken arasındaki ilişkinin veya bağlılığın olup olmadığını, var olduğu takdirde ilişkinin yönünü ve gücünü ölçmede kullanılan analiz tekniğidir. Korelasyon analizinde korelasyon katsayısı " $r$ " olarak gösterilmektedir. Bu katsayı (-1) ile (+1) arasında bir değer olabilir. Katsayı $-1,00$ ise, değişkenler arasında negatif ilişki olduğunu; 1,00 ise, değişkenler arasında pozitif ilişki olduğunu; 0,00 ise değişkenler arasında herhangi bir ilişkinin olmadığını gösterir. Bununla birlikte değişkenler arasındaki " $r$ " değerinin 0,00-0,29 arasında olması "düşük", 0,30-0,69 arasında olması "orta", 0,70 ve üzerinde olması ise "yüksek" düzeyde ilişkinin olduğu yönündedir (Ural ve Kılıç, 2006).

Tablo 4'te restoranları ziyaret eden yerli turistlerin gıda güvenliği bilgisi (çapraz kirlenme, kişisel hijyen, temizlik, doğru pişirme/saklama) ile şikâyet etme davranışı arasındaki ilişkinin ortaya çıkarılmasına yönelik "Korelasyon Analizi" sonuçları gösterilmektedir. Yapılmış olan korelasyon analizinde, çapraz kirlenme, kişisel hijyen, temizlik ve doğru pişirme/saklama bağımsız değişkenler; şikâyet etme davranışı ise bağımlı değişken olarak analize tabi tutulmuş ve 0,01 anlamlılık düzeyinde bir ilişki aranmıştır. 
Tablo 4: Turistlerin Şikâyet Etme Davranışı ile Gıda Güvenliği Bilgisi Arasındaki İlişkiye Ait Korelasyon Analizi

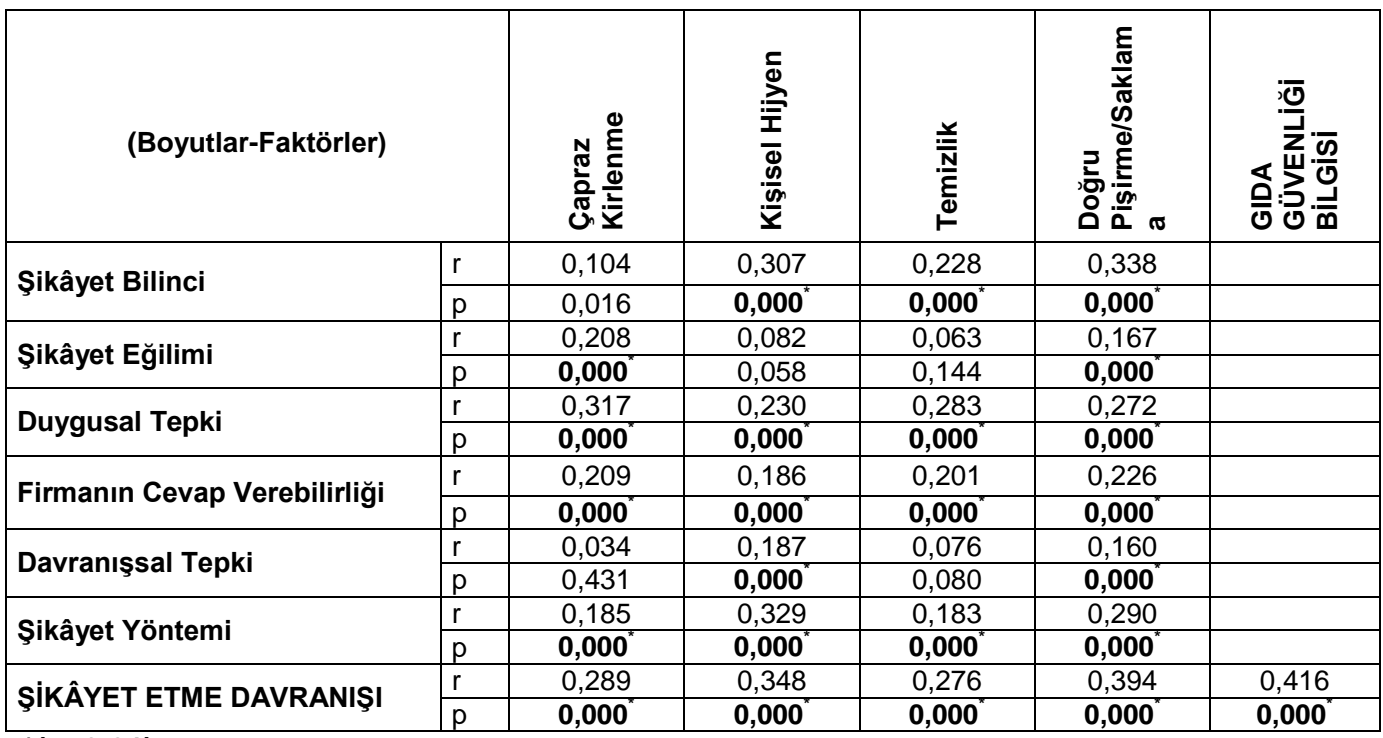

${ }^{*}(p<0,01)$

Restoranlarda yiyecek ve içecek hizmeti talep eden turistlerin gıda güvenliği bilgisi ile şikâyet etme davranışları arasındaki anlamlı ilişkinin $(r=0,416 ; p<0,00)$ nedensonuç bağlamında yorumlanabilmesi için basit doğrusal regresyon analizi yapılmış ve Tablo 5'teki sonuçlara ulaşılmıştır. Regresyon analizi; bir araştırma kapsamında belirlenen bir bağımlı değişken ile bağımsız değişken(ler) arasındaki ilişkinin matematiksel modelle açıklanmasını ve bağıntı(lar) kurulmasını esas alır (Ayaz, 2012: 199).

Restoranları ziyaret eden yerli turistlerin gıda güvenliği bilgilerinin şikâyet etme davranışlarına etkisini ölçmeye yönelik basit doğrusal regresyon analizinde gıda güvenliği bilgilerinin $(\beta=0,362$ ve $(p=0,000, p<0,001)$ anlamlılık düzeyinde olmak üzere şikâyet etme davranışını olumlu şekilde etkilediği tespit edilmiştir. Bu sonuçlar kapsamında yerli turistlerin gıda güvenliği bilgilerinin bir birim artması durumunda, şikâyet etme davranışlarının 0,362 ( $\beta$ ) kadar artacağı düşünülebilir. Bununla birlikte Tablo 5'teki verilere göre, uygulanan regresyon modeline ait $111,176(F)$ ve $0,173\left(R^{2}\right)$ değerlerine bakıldığında modelin 0,01 anlamlılık düzeyinde olduğu görülmektedir. Ayrıca, araştırma modeline göre turistlerin gıda güvenliği bilgilerinin şikâyet etme davranışlarını \%17 oranında açıkladığı şeklinde yorumlanabilir. Bu sonuç kapsamında araştırmanın ana hipotezi olan $\mathbf{H}_{\mathbf{1}}$ kabul edilmiştir.

Tablo 5: Turistlerin Gıda Güvenliği Bilgisinin Şikâyet Etme Davranışına Etkisine Yönelik Basit Doğrusal Regresyon Analizi

\begin{tabular}{|l|l|l|l|l|l|l|}
\hline $\begin{array}{l}\text { Bağımlı } \\
\text { Değişken }\end{array}$ & $\begin{array}{l}\text { Bağımsız } \\
\text { Değişken }\end{array}$ & $\mathbf{( \beta )}$ & $\mathbf{t}$ & $\mathbf{p}$ & $\mathbf{F}$ & $\mathbf{R}^{\mathbf{2}}$ \\
\hline $\begin{array}{l}\text { Şikâyet Etme } \\
\text { Davranışı }\end{array}$ & $\begin{array}{l}\text { Gıda Güvenliği } \\
\text { Bilgisi }\end{array}$ & 0,362 & 10,544 & $\mathbf{0 , 0 0 0 *}$ & 111,176 & 0,173 \\
\hline
\end{tabular}

${ }^{*}(p<0,01)$ 
Araştırma kapsamında öngörülen alt hipotezlerin test edilmesi bağlamında ise çoklu regresyon analizi yapılmış ve Tablo 6'daki sonuçlara ulaşılmıştır.

Tablo 6: Turistlerin Gıda Güvenliği Bilgileri İle Şikâyet Etme Davranışı Arasındaki İlişkiye Ait Çoklu Regresyon Analizi

\begin{tabular}{|c|c|c|c|c|c|c|}
\hline $\begin{array}{l}\text { Bağımlı } \\
\text { Değişken }\end{array}$ & $\begin{array}{l}\text { Bağımsız } \\
\text { Değişkenler }\end{array}$ & $(\beta)$ & $t$ & $p$ & $\mathbf{F}$ & $\mathbf{R}^{2}$ \\
\hline \multirow{5}{*}{$\begin{array}{l}\text { Şikâyet Etme } \\
\text { Davranışı }\end{array}$} & Sabit & 2,132 & 16,021 & $0,000^{\star}$ & \multirow{5}{*}{$33,033^{\star}$} & \multirow{5}{*}{0,200} \\
\hline & Çapraz Kirlenme & 0,020 & 0,695 & 0,488 & & \\
\hline & Kişisel Hijyen & 0,158 & 4,746 & $0,000^{*}$ & & \\
\hline & Temizlik & 0,027 & 0,854 & 0,394 & & \\
\hline & Doğru Pişirme/Saklama & 0,193 & 5,322 & $0,000^{*}$ & & \\
\hline
\end{tabular}

$*(\mathbf{p}<\mathbf{0 , 0 1})$

Turistlerin gıda güvenliği bilgisinde çapraz kirlenme $(p=0,488, p>0,01)$ ve temizliğin $(p=0,394, p>0,01)$ şikâyet etme davranışlarını etkilemediği görülmektedir. Bu sonuçlar kapsamında araştırma kapsamında önerilen $\mathbf{H}_{1-1}$ ve $\mathbf{H}_{1-3}$ hipotezleri bu araştırma için kabul edilmemiştir. Turistlerin gıda güvenliği bilgisinde kişisel hijyen $(\beta=0,158 ; p=0,000, p<0,01)$ ve doğru pişirme/saklamanın $(\beta=0,193 ; p=0,000, p<0,01)$ 0,01 anlamlılık düzeyinde olmak üzere, şikâyet etme davranışını pozitif yönde etkilediği tespit edilmiştir. Bu sonuçlar kapsamında araştırma kapsamında önerilen $\mathbf{H}_{\mathbf{1 - 2}}$ ve $\mathbf{H}_{1-4}$ hipotezleri bu araştırma için kabul edilmiştir. Ayrıca, turistlerin kişisel hijyen bilgileri bir birim artığında şikâyet etme davranışının 0,158 ( $\beta)$ kadar artacağı; doğru pişirme/saklama bilgilerinin bir birim artması durumunda ise şikâyet etme davranışının 0,193 ( $\beta$ ) kadar artacağı söylenebilir. Turizm literatüründe yiyecek ve içecek işletmelerinde ortaya çıkan şikayetler; işletme atmosferi, sunum, personel davranışları, fiyat, yiyecek ve içeceklerin içeriği ve tadı, sağlık kaygısı, hijyen koşulları ve orijinallik olarak sıralanmaktadır (Gursoy, McCleary ve Lepsito 2003; Baek, Ham ve Yang, 2006, Mattila ve Ro 2008, Law, To ve Goh, 2008, Liu ve Jang, 2009). Bu araştırmada da restoran işletmeleri için kişisel hijyen ve sağlık koşulları, şikayet etme davranışında öne çıkmıştır. Tablo 6'daki verilere göre uygulanan regresyon modeline ait 33,033 (F) ve $0,200\left(R^{2}\right)$ değerlerine bakıldığında modelin 0,01 anlamlılık düzeyinde olduğu görülmektedir. Araştırma modelinde yer verilen bağımsız değişkenlerin (kişisel hijyen ve doğru pişirme/saklama) turistlerin şikâyet etme davranışını \%20 oranında açıkladığı ifade edilebilir. Ayrıca ana hipotez ve alt hipotezleri kabul edilme veya kabul edilmeme durumları Şekil 2'de gösterilmiştir. 
Şekil 2: Araştırma Modeli Üzerinde Hipotezlerin Gösterimi

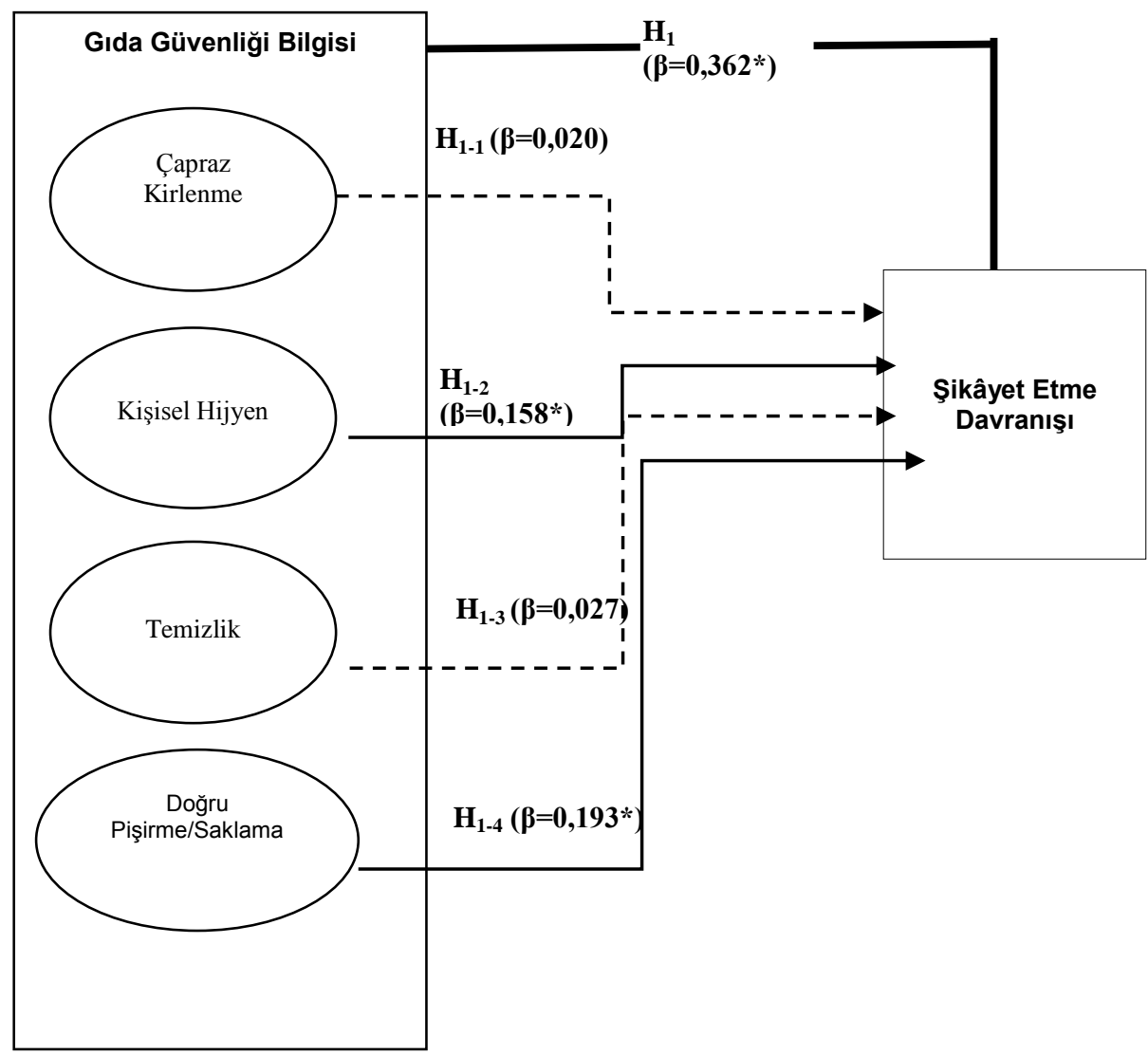

\section{$\beta=$ Beta Katsayısı \\ ${ }^{*}(p<0,01)$}

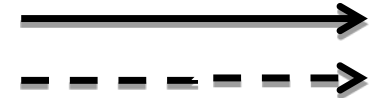

Anlamlı ilişki vardır.

Anlamlı ilişki yoktur.

\section{Sonuç ve Öneriler}

Sağlığın korunması ve yaşamın sürdürülebilir olması için yeterli ve dengeli bir şekilde besin ihtiyacının karşılanması ile birlikte tüketilen gıdaların güvenliği de önem arz etmektedir. Bu nedenle gıda güvenliği, yiyecek ve içecek hizmeti sunan teknik birimler için önemli bir bileşen olarak görülmelidir. Bu bileşenin göz ardı edilmesi halinde işletmeler için müşteri kaybı, kötü imaj ve yasal sorunlar kaçınılmaz durumlardır. Özellikle insanların gıda güvenliği konusunda bilinçlenmesi ve memnun kalmadıkları durumlar için şikâyetlere yol açabilmektedir. Gıda güvenliği konusunda tüketicileri şikâyet etmeye yönelten nedenler; kişisel hijyen, doğru pişirme ve saklama, çapraz kirlenme ve temizlik ana boyutları ile ilişkilendirilmektedir. Özellikle turizm gibi kırılgan sektörlerdeki müşteriler için gıda güvenliği önemli bir gereklilik olarak kabul görmektedir.

Yiyecek ve içecek hizmet birimi olarak restoranlar, bir destinasyonda ziyaretçilerin beslenme intiyaçlarının karşılandığı işletmelerdir. Ziyaretçilerin restoran tercihlerinde işletmenin konumu, ortamı, ambiyansı, dekorasyonu vb. unsurlar etkili 
olmaktadır. Bunun yanında yiyecek ve içeceklerin sağlıklı, güvenilir ve kaliteli olması, işletme personelinin gıda güvenliği uygulamalarını gerçekleştirmesi restoranın tercih edilebilirliğini etkilemektedir. Restoranlar, insanlara gıda hizmeti sunmadaki kolaylıklarının yanı sıra gıda kaynaklı hastalıkların en sık görüldüğü ortamlardan birisidir. Bir restoran çalışanının yapacağı bir gıda güvenliği hatası, birçok kişiyi olumsuz (hastalık, sakatlık, tazminat, hapis vb.) etkileyebilir.

$\mathrm{Bu}$ araştırmada restoranlardan yiyecek ve içecek hizmeti talep eden yerli turistlerin gıda güvenliği bilgilerinin şikâyet davranışlarına etkisi test edilmiştir. Araştırma sonuçlarına göre restoranları ziyaret eden yerli turistlerin şikâyet davranışı ile gıda güvenliği bilgisi arasında pozitif yönlü ilişki bulunmaktadır. Ayrıca gıda güvenliği bilgisi ve gıda güvenliği bilgisi alt boyutlarının (kişisel hijyen, doğru pişirme/saklama) şikayet etme davranışını pozitif yönde etkilediği saptanmıştır. Elde edilen bulgular kapsamında turizm destinasyonlarında turistlerin intiyaçlarını karşılayabileceği işletmelerden biri olan restoranlar, sunduğu yiyecek ve içeceklerde gıda güvenliği konusunda kendilerini geliştirmelidirler. Özellikle emek yoğun hizmet işletmeleri olan bu işletmelerde personelin gıda güvenliği konusunda bilinçleneceği seminer ve eğitim çalışmaları düzenlenmesi, personellerin kendilerini geliştirmesinde yol gösterici olabilecektir.

Restoranlar, sundukları yiyecek içecek hizmetlerinden dolayı müşterilerinde meydana gelecek herhangi bir gıda zehirlenmesinden sorumlu olacaklarından gıda güvenliği konusunda gereken hassasiyeti göstermeleri gerekmektedir. Bu bağlamda çapraz kirlenme, doğru pişirme ve saklama, temizlik, kişisel hijyen gibi hususlarda gereken özeni göstermeleri faydalı bir yaklaşım olacaktır. Sunulan hizmetlerden memnun kalmayarak gıda güvenliğine yönelik şikâyet davranışı sergileyen müşterilere şikâyetleri konusunda çözümcü yaklaşılmalı, şikâyetleri en aza indirebilecek şekilde temizlik, doğru pişirme/saklama, kişisel hijyen ve çapraz kirlenme gibi gıda güvenliğine yönelik hizmetlerin yükseltilmesi çabalarına odaklanılmalıdır.

Restoranlar misafirlerine güvenli gıdalar adına HACCP ve ISO 22000 gibi gıda güvenliğine yönelik programları bünyelerine taşıyarak daha güvenli gıdalar sunabilirler. Restoranlar müşterilerden masaya bırakılabilecek kısa soru anketler, şikâyet kutuları ve şikâyet defterleri kullanmak suretiyle geri bildirim toplayabilir. Bu geri bildirimlere yönelik analiz sonuçlarını personelleri ile paylaşarak hizmet kalitesini artırabilirler.

$\mathrm{Bu}$ araştırmada, restoranları ziyaret eden yerli turistlerin gıda güvenliği bilgileri ve şikâyet etme davranışları kapsamında kavramsal bir yapı oluşturulmuştur. Çalışmada yerli turistlerin şikâyetleri restoran işletmeleri boyutuyla ele alınmıştır. Benzer çalışmalarda başka turizm işletmeleri (oteller, tatil köyleri vb.) incelenebilir. Yerli turistlerin şikâyet davranışları; şikâyet bilinci, şikâyet eğilimi, duygusal tepki, firmanın cevap verebilirliği, davranışsal tepki ve şikâyet yöntemi olarak irdelenmiştir. Benzer çalışmalarda başka boyutlarla ilişkilendirilebilir. Yerli turistlerin gıda güvenliği bilgileri; çapraz kirlenme, kişisel hijyen, temizlik ve doğru pişirme/saklama alt boyutları ile incelenmiştir. Gelecekte yapılması öngörülen çalışmalarda yerli turistlerin gıda güvenliği bilgisine yönelik başka boyutlar (gıda malzemeleri, su, vb.) odaklanılması farklı bakış açıları ortaya çıkarılabilir.

\section{Kaynakça}

Albayrak, A. (2013). 'Restoran İşletmelerinde Müşteri Şikâyetleri ve Şikâyete İlişkin Davranışlar'. Paradoks Ekonomi, Sosyoloji ve Politika Dergisi, 9(2), ss. 27-51. 
Ayaz, N. (2012). Kırsal Turizm ve Paydaşları: Belediye Başkanlarının Tutumlarına Yönelik Bir Araştırma. Yayınlanmamış Doktora Tezi, Gazi Üniversitesi, Eğitim Bilimleri Enstitüsü, Ankara.

Ayaz, N. ve Acar, A. (2018). Turizm İşgörenleri İçin Gıda Güvenliği El Kitabı. Ankara: Detay Yayıncılık.

Ayaz, N. ve Sünbül, K. (2018). 'Restoran Müşterilerinin Beklentileri ve Gıda Güvenliğine Yönelik Tepkileri Üzerine Bir Nitel Araştırma'. Journal of Tourism and Gastronomy Studies, 6(1), ss.164-181.

Başaran, B. (2016). 'ISO 22000 Gıda Güvenliği Yönetim Sistemi'. Journal of Food and Healt Science, 2(1), ss. 9-26.

Baek, S. H., Ham, S. ve Yang, I. S. (2006). 'A Cross-Cultural Comparison of Fast Food Restaurant Selection Criteria Between Korean and Filipino College Students'. International Journal of Hospitality Management, 25(4), ss. 683-698.

Bell, S. J., Mengüç, B. ve Stefani, S. L. (2004). 'When Customers Disappoint: A Model of Relational Internal Marketing and Customer Complaints'. Journal of the Academy of Marketing Science, 32(2), ss. 112-126.

Beulens, A. J. M., Broens, D. F., Folstar, P. ve Hofstede, G. J. (2005). 'Food Safety and Transparency in Food Chains and Networks'. Food Control, 16(6), ss. 481486.

Bolton, D. J., Meally, A., Blair, I. S., McDowell, D. A. ve Cowan C. (2008). 'Food Safety Knowledge of Head Chefs and Catering Managers in Ireland'. Food Control, 19(3), ss. 291-300.

Çatı, K., Koçoğlu, C. M. ve Gelibolu, L. (2010). 'Müşteri Beklentileri ile Müşteri Sadakati Arasındaki İlişki: Beş Yıldızıı Bir Otel Örneği'. Çukurova Üniversitesi Sosyal Bilimler Enstitüsü Dergisi, 19(1), ss. 429-446.

Defranco, A., Wortman, J., Lam, T. ve Countryman, C. (2005). 'A Cross-Cultural Comparison of Customer Complaint Behavior in Restaurants in Hotels'. Asia Pacific Journal of Tourism Research, 10(2), ss. 173-190.

Dehghan, P., Azar, F. P., Aghdash, S. A., Silabi, Y. S., Dadkhah, H. ve Aghdash, H. M. (2017). 'Knowledge and Attitude Towards Health And Food Safety Among Students of Tabriz University of Medical Sciences, Tabriz, Iran'. Journal of Analytical Research in Clinical Medicine, 5(2), ss. 62-68.

Deniz, D., Küçük, B., Cansız, Ş., Akgün, L. ve İşleyen, T. (2014). 'Ortaöğretim Matematik Öğretmeni Adaylarının Üstbiliş Farkındalıklarının Bazı Değişkenler Açısından İncelenmesi'. Kastamonu Eğitim Dergisi, 22(1), ss. 305-320.

Gümüşbuğa, F. (2016). 'Bankacılıkta Müşteri İlişkileri Yönetiminin Müşteri Sadakatine Etkisi'. Turkish Journal of Marketing, 1(1), ss. 76-93.

Gursoy, D., McCleary, K. W. ve Lepsito, L. R. (2003). 'Segmenting Dissatisfied Restaurant Customers Based on Their Complaining Response Styles'. Journal of Foodservice Business Research, 6(1), ss. 25-43.

http://www.gidamo.org.tr/resimler/ekler/85454e8279be180_ek.pdf?dergi=18> [Erişim Tarihi: 20 Şubat 2018].

http://www.who.int/whosis/whostat2007.pdf?ua=1> [Erişim Tarihi: 11 Kasım 2017].

https://arastirma.tarim.gov.tr/alata/Belgeler/Digerbelgeler/G\%C4\%B1daG\%C3\%BCven li\%C4\%9FiZKara\%C5\%9Fahin.pdf> [Erişim Tarihi: 20 Şubat 2018].

Keng, K. A ve Liu, S. (1997). 'Personal Values and Complaint Behaviour: The Case of Singapore Consumers'. Journal of Retailing and Consumer Services, 4(2), ss. 89-97.

Kitapcı, O. (2008). 'Restoran Hizmetlerinde Müşteri Şikâyet Davranışları: Sivas İlinde Bir Uygulama'. Erciyes Üniversitesi Iktisadi ve Idari Bilimler Fakültesi Dergisi, (31), ss. 111-120.

Kotler, P., Wong, V., Saunders, J. ve Armstrong, G. (2005). Principles of Marketing. (Fourth European Edition). Edinburgh: Pearson Education Limited. 
Law, R., To, T. ve Goh, C. (2008). 'How Do Mainland Chinese Travelers Choose Restaurants in Hong Kong? An Exploratory Study of Individual Visit Scheme Travelers and Packaged Travelers'. International Journal of Hospitality Management, 27(3), ss. 346-354.

Liu, Y. ve Jang, S. S. (2009). 'Perceptions of Chinese Restaurants in The US: What Affects Customer Satisfaction and Behavioral Intentions?'. International Journal of Hospitality Management, 28(3), ss. 338-348.

Mattila, A. S. ve Ro, H. (2008). 'Discrete Negative Emotions and Customer Dissatisfaction Response in A Casual Restaurant Setting'. Journal of Hospitality \& Tourism Research, 32(1), ss. 89-107.

Mucuk, İ. (2009). Pazarlama İlkeleri. İstanbul: Türkmen Kitabevi.

Purnomo, H. (2006). 'Food Safety in Hopitality Industry'. Jurnal Manajemen Perhotelan, 2(1), ss. 1-6.

Sekeran, U. (2003). Research Methods for Business. John Wiley \& Sons: The United States of America.

Sneed, J. ve Strohbehn, C. H. (2008). 'Trends Impacting Food Safety in Retail Foodservice: Implications for Dietetics Practice'. Journal of the American Dietetic Association, 108(7), ss. 1170-1177.

Şahin, A., Çakıcı, A. C. ve Güler, O. (2014). Tüketicilerin Masa Servisi Yapan Restoranlarda Önem Verdiği Hususların Şikâyet Davranışı Eğilimlerine Etkisi. 15. Ulusal Turizm Kongresi, 13-16 Kasım, Ankara.

Türker, N. ve Uçar, M. (2013). 'Konaklama İşletmelerinin Sosyal Sorumlulukları. İşletme Araştırmaları Dergisi', 5(3), ss. 155-183.

Türksoy, A. ve Altıniğne, N. (2008). 'Konaklama İşletmelerinde Gıda Güvenliği ve Çeşme İlçesinde Yer Alan Turizm Belgeli Konaklama Tesislerinde Gıda Güvenliği Uygulamalarının Değerlendirilmesi'. Ege Academic Rewiew, 8(2), ss. 605-629.

Ural, A. ve Kılıç, İ. (2006). Bilimsel Araştırma Süreci ve SPSS ile Veri Analizi. Ankara: Detay Yayıncılık.

Usta, R. (2006). 'Mobilya Sektöründe Tüketici Tatmini ve Şikâyet Davranışı: Karabük İlinde Bir Araştırma'. Gazi Üniversitesi İktisadi ve İari Bilimler Fakültesi Dergisi, 8(1), ss. 121-138.

Yılmaz, Y., Semerci, A., Tapkı, N., Dağıstan, E. ve Konuşkan, D. B. (2015). 'Consumers' Knowledge, Attitudes and Behavior Assessment about Food Safety: The Case Study of Hatay Province of Turkey'. Turkish Journal of Agriculture-Food Science and Technology, 3(8), ss. 672-679. 